ISSN 1682-5268 (on-line); ISSN 1608-0599 (print)

Shìdnij svìt, 2021, No. 1, pp. 155-156

doi: https://doi.org/10.15407/orientw2021.01.155

New word about Ukraine and the Orient. Presentation of the edition: Academic Edition of Lesya Ukrainka's Complete Works: in 14 volumes. Volume 10. "Ancient History of Oriental Peoples". Conspectuses. Extracts from books. Notes and more / Ed. Yu. Gromyk; foreword by O. Ohnieva; compiled by A. Radko, O. Ohnieva, I. Biskub at all; commentaries by O. Ohnieva, V. Pryimachenko, O. Romanova at all. Lutsk: Lesya Ukrainka Volyn National University, 2021. 528 p., 56 il. p.

\title{
O. Ohnieva
}

$\mathrm{PhD}$ (History), Senior Fellow

A. Yu. Krymskyi Institute of Oriental Studies, NAS of Ukraine

4, Hrushevskoho Str., Kyiv, 01001, Ukraine

gulripsh17@gmail.com

At the beginning of 2021, Academic Edition of Lesya Ukrainka's Complete Works: in 14 volumes was published containing all the writings of the author found to date. The collection of works includes restored fragments and materials that were removed by censorship in previous editions. Each volume is accompanied by extensive comments. The edition was prepared for publication by specialists from Lesya Ukrainka Volyn National University, Lesya Ukrainka Research Unit of the University, as well as other institutions of higher education and academic institutions, including A. Yu. Krymskyi Institute of Oriental Studies, NAS of Ukraine. Scholars of A. Yu. Krymskyi Institute of Oriental Studies Dmytro Burba, Olena Ohnieva, Vitaliy Pryimachenko, Olena Romanova took part in the preparation for the publication of the $10^{\text {th }}$ volume. The works contained in it are different in their content: a textbook compiled by Lesya Ukrainka for her younger sister "Ancient History of Oriental Peo-

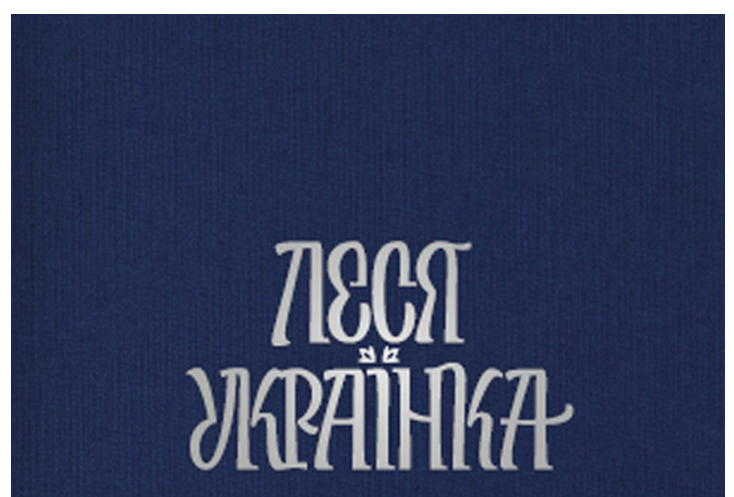
ples", as well as the author's illustrations, abstracts and extracts from books, notes and materials to the fiction writings of the author. The vast majority of the texts presented in this volume are introduced for the first time.

Keywords: Lesya Ukrainka, Academic Edition of Lesya Ukrainka's Complete Works, A. Yu. Krymskyi Institute of Oriental Studies of the National Academy of Sciences

(C) 2021 O. Ohnieva; Published by the A. Yu. Krymskyi Institute of Oriental Studies, NAS of Ukraine on behalf of The World of the Orient. This is an Open Access article distributed under the terms of the Creative Commons Attribution License (https://creativecommons.org/licenses/by-nc/4.0/).

The World of the Orient, 2021, № 1 
Нове слово про Україну і Схід. Презентація видання: Леся Українка. Повне академічне зібрання творів: у 14 томах. Том 10. “Стародавня історія східніх народів”. Конспекти. Виписки з книг. Нотатки та інше / ред. Ю. Громик; передм. О. Огнєва; упоряд. А. Радько, О. Огнєва, І. Біскуб та ін.; комент. О. Огнєва, В. Приймаченко, О. Романова та ін. - Луцьк: Волинський національний університет імені Лесі Українки, 2021. -528 с., 56 с. іл.

25 лютого Україна урочисто відсвяткувала 150-річчя від дня народження Лесі Українки. До цієї знаменної події українці дістали чудовий подарунок - повне академічне зібрання творів у 14 томах. До зібрання увійшли всі знайдені на сьогодні тексти письменниці. Томи видання містять відновлені фрагменти і матеріали, що вилучались цензурою в попередніх виданнях. Кожний том супроводжений розлогими коментарями. Видання до друку готували фахівці Волинського національного університету імені Лесі Українки, Науково-дослідного інституту Лесі Українки при університеті, а також інших закладів вищої освіти та академічних установ, зокрема й Інституту сходознавства ім. А. Ю. Кримського.

Науковці Інституту сходознавства брали участь у підготовці до видання 10-го тому. Цей том привертає увагу своєю розмаїтістю, яка підкреслює талановитість особистості Лесі Українки. Твори, що включено до нього, різні за складом: “Стародавня історія східніх народів”, конспекти, виписки з книг, нотатки тощо. Причому залежно від використаного джерела їх наведено мовою оригіналу: крім рідної мови, представлено англійську, німецьку, російську, французьку. Усі твори або вперше 3'являються у складі багатотомного паперового видання, як-от “Стародавня історія східніх народів”, назва якої в зібранні творів збережена згідно з творчою волею Лесі Українки, або взагалі вперше вводяться до обігу (переважна більшість текстів), або частково вже відомі. А минулорічна (2020р.) листопадова аудіопублікація Тамарою Скрипкою доповіді Ізидори Косач-Борисової (від 1963 р.), сестри Лесі Українки, чи виявлене нове фото поетеси з їі дарчим написом Ользі Кобилянській дарують надію ще на нові знахідки, зокрема й аудіо, й образотворчі.

“Стародавня історія східніх народів” репрезентує Давній Схід, адресований тринадцятирічній дівчинці, очима дев’ятнадцятирічної дівчини, яка дістала домашню освіту. Рукопис історії, промандрував від Луцька та Колодяжного до Сгипту та Грузії і повернувся в Україну. Світи Стародавнього Сходу поставали джерелом натхнення протягом усього творчого шляху Лесі Українки, аж до “Лісової пісні" включно. Виписки зі Старого Завіту, листів Олівера Кромвеля, дослідження Франсуа Гізо, відомого французького історика і державного діяча, Леся Українка використала для написання драми "У пущі", так само як і виписки 3 праці знаного психіатра Ріхарда фон Краффт-Ебінга для “Блакитної троянди”. Один аркуш із визначенням "Музика до Гейне" з переліком імен композиторів, а серед них домінує ім'я Роберта Шумана, доповнює знання про світ їі музичних і поетичних захоплень. Представлено виписки з творів Тараса Шевченка, французьких поетів, фрагмент 3 автографа фольклорних записів Лариси та Михайла Косачів, що зберігається в Москві, та інші, не менш цікаві матеріали.

Авторський колектив тому 10 становлять викладачі та науковці Волинського державного університету, Науково-дослідного інституту Лесі Українки Оксана Бєлих, Ірина Біскуп, Людмила Бондарук, Юрій Громик, Антоніна Радько та наукові співробітники Інституту сходознавства ім. А. Ю. Кримського НАН України Дмитро Бурба, Олена Огнєва, Віталій Приймаченко, Олена Романова. Їхня копітка робота спиралась на матеріали, що зберігаються в Києві і за його межами, наприклад у Москві, на листування, численні дослідження та публікації творів, що після їхнього опрацювання ставали підгрунтям для роботи над тим чи іншим твором - чи то драмою, чи то поезією, чи історією. I, без сумніву, у наступні роки знову дослідникам вдасться віднайти нові, ще не відомі матеріали, які подарують неочікувану зустріч із Лесею Українкою.

О. Д. Огнєва 